\title{
Obituaries.
}

The Council greatly regret to record the deaths of the following members of the Society during the year:-

Sir Richard Tetley Glazebrook, F.R.S., Honorary Fellow, i854-I936.

Richard Tetley Glazebrook was born in Liverpool on September 18th, I854. He graduated as Fifth Wrangler in 1876 and was elected a Fellow of Trinity College, serving from r881-1896 as lecturer and assistant tutor. In 1880 he was appointed a demonstrator at the Cavendish Laboratory by Lord Rayleigh and later became assistant director. He was largely concerned there with teaching practical physics with Sir Napier Shaw, their work forming the foundation of the Textbook of Practical Physics. Glazebrook published a number of papers on the theory of light and the determination of fundamental electrical units, and in I 882 was made a Fellow of the Royal Society, afterwards, in 1909, receiving the Hughes Medal and in r93I the Royal Medal.

In 1898 Glazebrook became Principal of University College, Liverpool, and the following year was appointed the first director of the National Physical Laboratory, from which post he retired in igig. The work which Glazebrook did at the N.P.L. was of incalculable value. It comprised only two departments at its opening, physics and engineering, with a total staff of only 26 . When he retired the staff had increased twentyfold and new departments had been formed, including that of aeronautics.

Glazebrook's range of activities covered almost every branch of science. He was for many years the secretary of the Electrical Standards Committee of the British Association, was President of the Institution of Electrical Engineers (1906-7), of the Physical Society (1903-5), and of the Optical Society (1903-4, I9II-I 2). He was chairman of the Advisory Committee for Aeronautics from its formation in 1909 , and also until 1933 of the Aeronautical Research Committee which succeeded it in 1920. From $1920-23$ he was Zàharoff Professor of Aviation and Director of the Aeronautics Department in the Imperial College of Technology. In 1933 he was awarded the Gold Medal of the Royal Aeronautical Society, a member of which he had been for many years. The author of many papers and textbooks, he was the Editor of the Dictionary of Applied Physics. He was knighted in 1917.

By the death of Sir Richard Glazebrook aviation lost one of its leading figures who, by his work at the N.P.L. and as chairman of the A.R.C., did much to make the science of aeronautics what it is to-day.

\section{JoHN LORD, Fellow, 1936.}

By the sudden death of John Lord on January $25^{\text {th }}$ aviation lost one of its best known and best beloved figures. He saw the growth of aviation from the beginning, joining A. V. Roe when the latter began making aeroplanes in rgog-ro. He did not have an opportunity to show his real worth and organising ability until the last two years of the Great War. From that time he rose rapidly until he became known to everyone in the aircraft industry as a man of the highest ability and integrity. Much of the outstanding success of A. V. Roe and Co., indeed, can be traced to his managership.

When the firm was absorbed into the Siddeley organisation John Lord and A. V. Roe retired, and with S. Saunders, the motor boat pioneer, founded Saunders-Roe, Ltd., which with its series of amphibians rapidly became one of the leading firms in the country.

John Lord joined the Society in $19 \mathrm{r} 2$ and was elected a Fellow in 1928. He was for many years a member of the Finance Committee and did much to help the Society in its many activities. He was a man who made no enemies but innumerable friends, and by his death aviation lost not only one of its pioneers, but one who will be long remembered for his kindliness, generosity and ability. 